\title{
Effects of Unilateral Renal Arterial Constriction on Tubular Reabsorption of Sodium and Water during an Osmotic Diuresis*
}

\author{
Richard M. Stein, $\dagger$ Ruth G. Abramson $\ddagger$ D. Danny Bercovitch $\$$ and \\ MARVIN F. LeVITT
}

(From The Mount Sinai Hospital, New York, N. Y.)

Previous studies have indicated that acute reductions in glomerular filtration rate (GFR), during loading with nonreabsorbable solute, increase the fraction of the filtered sodium load reabsorbed (1-3). The renal tubular sites at which this enhanced reabsorption develops have not been elucidated. Recent studies from this laboratory in which mannitol loads were administered to salt-depleted subjects with modest reductions in GFR suggested that sodium reabsorption was enhanced within the proximal tubule (4). However, it was not possible to determine whether renal hemodynamics or other, perhaps hormonal, factors were responsible for the increased reabsorption at this site. The present studies were designed to evaluate the specific effects of a reduction in GFR produced by renal arterial constriction on tubular sodium reabsorption. We propose that renal arterial constriction during loading with nonreabsorbable solute provokes an enhanced reabsorption of sodium, in large part within the proximal tubule.

\section{Methods}

Experiments were performed in seven hydrated and eight hydropenic female mongrel dogs (17 to $24 \mathrm{~kg}$ ), anesthetized with ethyl carbamate and $\alpha$-chloralose administered intravenously. After appropriate priming doses of inulin and para-aminohippurate $(\mathrm{PAH})$, a sustaining solution containing a sufficient amount of inulin and $\mathrm{PAH}$

* Submitted for publication February 16, 1965 ; accepted July 6, 1965.

These studies were supported by U. S. Public Health Service research grant HE-08535 from the National Heart Institute.

Presented in abstract form at the Fifty-sixth Annual Meeting of the American Society for Clinical Investigation, May 1964. (J. clin. Invest. 1964, 43, 1296.)

$\dagger$ Address requests for reprints to Dr. Richard M. Stein, Mount Sinai Hospital, 100th St. and Fifth Ave., New York, N. Y. 10029.

$\ddagger$ National Institutes of Health postdoctoral fellow. to maintain adequate blood levels was infused with a Bowman constant infusion pump. These substances were administered in $0.45 \%$ saline and in $0.9 \%$ saline in the experiments performed under hydrated and hydropenic conditions, respectively. Aqueous vasopressin was also included in the constant infusion in studies performed in the hydropenic state and was administered at $50 \mathrm{mU}$ per $\mathrm{kg}$ body weight per hour to insure sustained maximal antidiuresis.

One renal artery was approached retroperitoneally through a flank incision. An open Blalock clamp was positioned around the isolated vessel and secured in place by a multiangle brace. Catheters were introduced into the distal ureters through a mid-line suprapubic incision. Urine collections (10 to 20 minutes in duration) were obtained simultaneously from both kidneys throughout each study. Mid-point blood specimens were obtained at appropriate intervals. This protocol includes only those experiments in which there was less than a $10 \%$ disparity in the rates of urine flow from the two kidneys.

Studies performed under hydrated conditions. Animals studied in the hydrated state received water ad libitum, but were deprived of food during the 24 hours before each experiment. Water hydration was induced with a $2.5 \%$ glucose solution (six studies) or $1.25 \%$ glucose plus $0.2 \%$ saline (one study) infused at $10 \mathrm{ml}$ per minute until a load of approximately $50 \mathrm{ml}$ water per $\mathrm{kg}$ body weight had been administered. After urine flow had increased and stabilized, two to three urine collection periods were obtained. The renal artery was then constricted until a stable reduction in urine flow of 40 to $70 \%$ was produced in the experimental kidney. After one or two additional collection periods had been obtained, a $2.5 \%$ mannitol solution (containing $0.2 \%$ saline in one study and $0.15 \%$ saline in another) was substituted for the glucose solution and administered at progressively increasing rates throughout the remainder of the experiment.

Studies performed under hydropenic conditions. Experiments were performed in animals that had been deprived of both food and water for 24 hours and had received $5 \mathrm{U}$ vasopressin tannate in oil intramuscularly 14 hours before each study. A hypertonic mannitol solution was administered at approximately $4 \mathrm{ml}$ per minute during the surgical procedure. Solutions contained $10 \%$ mannitol and $0.3 \%$ saline (four studies), $6 \%$ mannitol and $0.3 \%$ saline (one study), and $10 \%$ mannitol without 
saline (three studies). After all surgery had been completed and urine flow stabilized (at approximately $2 \mathrm{ml}$ per minute from each kidney) two to three collection periods were obtained. The renal artery was then constricted until a stable 30 to $50 \%$ reduction in urine flow was produced in the experimental kidney. Thereafter, the hypertonic mannitol solution was administered at progressively increasing rates throughout the study.

Urine and plasma specimens were analyzed for osmolality and sodium, potassium, chloride, inulin, and $\mathrm{PAH}$ concentrations by methods previously described from this laboratory (5). The clearances of inulin and PAH were utilized to represent GFR and effective renal plasma flow, respectively. The filtered sodium load was estimated as GFR (milliliters per minute) $\times$ plasma sodium concentration (milliequivalents per liter). No corrections were made for the Donnan effect. The fraction of the filtered load of sodium excreted (or $\mathrm{C}_{\mathrm{Na}} / \mathrm{GFR}$ ) was calculated as $\left(U_{\mathrm{Na}} \mathrm{V} /\right.$ filtered sodium $) \times 100$, where $U_{\mathrm{Na}}$ represents urinary sodium concentration (milliequivalents per liter) and $\mathrm{V}$ the urine flow rate (milliliters per minute). Plasma mannitol concentration was estimated as $\mathrm{P}_{\text {osm }}-2$ $\left(P_{N_{a}}\right)$, where $P_{o s m}$ and $P_{N a}$ represent plasma osmolality and plasma sodium concentration, respectively. Solute clearance $\left(\mathrm{C}_{\text {osm } m}\right.$ ) was calculated as $\mathrm{U}_{\text {osm }} \mathrm{V} / \mathrm{P}_{\text {os } m}$, where $U_{\text {osm }}$ represents urinary osmolality. Free water clearance
$\left(\mathrm{C}_{\mathrm{H}_{2} \mathrm{O}}\right)$ was calculated as $\mathrm{V}-\mathrm{C}_{\mathrm{osm}}$. Free water reabsorption $\left(\mathrm{T}^{\mathrm{c}} \mathrm{H}_{20} \mathrm{O}\right)$ was calculated as $\mathrm{C}_{\mathrm{osm}}-\mathrm{V}$.

\section{Results}

In studies performed under hydrated and hydropenic conditions constriction of one renal artery generally produced reductions in GFR (and renal plasma flow) up to $60 \%$ in the experimental kidney. Associated with the constriction of the renal artery, $\mathrm{U}_{\mathrm{Na}} \mathrm{V}$ and $\mathrm{U}_{\mathrm{Na}} \mathrm{V}$ /filtered sodium decreased markedly in the experimental kidney (fractional sodium reabsorption approached $100 \%$ ) (Tables I to III, Figure 1). Thereafter, during the course of the increasing osmotic diuresis $\mathrm{U}_{\mathrm{Na}} \mathrm{V}$ and $\mathrm{U}_{\mathrm{Na}} \mathrm{V} /$ filtered sodium rose appreciably on the control side, whereas these parameters increased only slightly on the constricted side (Tables I to III, Figure 1). In addition, after renal arterial constriction the fraction of urinary solute composed of sodium $\left(\mathrm{U}_{\mathrm{Na}} / \mathrm{U}_{\text {osm }}\right)^{1}$ decreased and re-

1 The net transtubular sodium concentration gradient established by the kidney may be expressed as $\mathrm{P}_{\mathrm{Na}}-\mathrm{U}_{\mathrm{Na}}$.

TABLE I

Typical experiment performed under hydrated conditions*

\begin{tabular}{|c|c|c|c|c|c|c|c|c|c|c|c|c|c|c|c|c|}
\hline \multirow[b]{2}{*}{ Time } & \multicolumn{2}{|c|}{$\mathrm{v}$} & \multicolumn{2}{|c|}{$\begin{array}{c}\text { Inulin } \\
\text { clearance }\end{array}$} & \multicolumn{2}{|c|}{$\mathrm{UNaV}_{\mathrm{Na}}$} & \multicolumn{2}{|c|}{$\frac{\mathrm{UNaV}_{\mathrm{Na}}}{\mathrm{F}}$} & \multicolumn{2}{|c|}{$\frac{U_{N a}}{U_{\text {osm }}}$} & \multicolumn{2}{|c|}{$\mathrm{UKV}_{\mathrm{K}}$} & \multicolumn{2}{|c|}{ Coem } & \multicolumn{2}{|c|}{$\mathrm{C}_{\mathrm{H}_{2} \mathrm{O}}$} \\
\hline & $\mathrm{L}$ & $\overline{\mathbf{R}}$ & $\mathrm{L}$ & $\mathbf{R}$ & $\mathrm{L}$ & $\mathbf{R}$ & $\mathbf{L}$ & $\mathbf{R}$ & $\mathbf{L}$ & $\overline{\mathbf{R}}$ & $\mathrm{L}$ & $\overline{\mathbf{R}}$ & $\mathbf{L}$ & $\mathbf{R}$ & $\mathbf{L}$ & $\mathbf{R}$ \\
\hline $\min$ & & \multicolumn{2}{|c|}{$m l / m i n$} & \multicolumn{2}{|c|}{$\mu E q / \min$} & \multicolumn{2}{|c|}{$\%$} & & & \multicolumn{2}{|c|}{$\mu E q / \min$} & \multicolumn{2}{|c|}{$m l / \min$} & \multicolumn{2}{|c|}{$m l / m i n$} \\
\hline 0 & \multicolumn{16}{|c|}{$\begin{array}{l}\text { Primes administered. Constant infusion started: inulin } 25 \mathrm{mg} \text { per minute, PAH } 4 \mathrm{mg} \text { per minute } \\
\text { in } 0.45 \% \mathrm{NaCl} \text { at } 1.0 \mathrm{ml} \text { per minute. }\end{array}$} \\
\hline 105 & \multicolumn{16}{|c|}{ Surgery completed. } \\
\hline 120 & \multicolumn{16}{|c|}{$1.25 \%$ glucose in $0.2 \% \mathrm{NaCl}$ administered intravenously at $10 \mathrm{ml}$ per minute. } \\
\hline $220-230$ & 5.00 & 4.85 & 46 & 43 & 18 & 20 & 0.3 & 0.3 & .07 & .08 & 31 & 29 & 0.9 & 0.8 & 4.1 & 4.0 \\
\hline $230-240$ & 5.05 & 4.88 & 46 & 44 & 18 & 18 & 0.3 & 0.3 & .07 & .07 & 38 & 26 & 0.9 & 0.8 & 4.2 & 4.1 \\
\hline $240-290$ & \multicolumn{16}{|c|}{ Constriction of right renal artery. } \\
\hline $290-300$ & 4.65 & 2.70 & 47 & 42 & 14 & 9 & 0.2 & 0.1 & .06 & .05 & 21 & 15 & 0.8 & 0.6 & 3.8 & 1.1 \\
\hline 300 & \multicolumn{16}{|c|}{$\begin{array}{l}2.5 \% \text { mannitol in } 0.2 \% \mathrm{NaCl} \text { substituted for } 1.25 \% \text { glucose in } 0.2 \% \mathrm{NaCl} . \mathrm{M} \\
\text { at increasing rates throughout the remainder of the study. }\end{array}$} \\
\hline $330-340$ & 7.65 & 3.75 & 41 & 33 & 39 & 9 & 0.7 & 0.2 & .05 & .02 & 41 & 15 & 2.7 & 1.8 & 4.9 & 2.0 \\
\hline $340-350$ & 8.70 & 4.70 & 42 & 33 & 64 & 11 & 1.1 & 0.2 & .06 & .02 & 42 & 17 & 3.3 & 2.2 & 5.4 & 2.5 \\
\hline $350-360$ & 9.78 & 4.80 & 39 & 30 & 86 & 11 & 1.6 & 0.3 & .08 & .02 & 42 & 17 & 3.9 & 2.3 & 5.9 & 2.5 \\
\hline $360-370$ & 11.0 & 5.15 & 40 & 27 & 108 & 12 & 2.0 & 0.3 & .08 & .02 & 42 & 16 & 4.4 & 2.5 & 6.6 & 2.7 \\
\hline $370-380$ & 12.5 & 5.00 & 41 & 25 & 148 & 13 & 2.7 & 0.4 & .09 & .02 & 46 & 16 & 5.3 & 2.5 & 7.2 & 2.5 \\
\hline $380-390$ & 13.7 & 6.20 & 42 & 27 & 206 & 16 & 3.8 & 0.5 & .11 & .02 & 51 & 20 & 6.4 & 3.2 & 7.3 & 3.0 \\
\hline $390-400$ & 14.0 & 6.50 & 42 & 24 & 188 & 15 & 3.4 & 0.5 & .09 & .01 & 52 & 20 & 6.7 & 3.5 & 7.3 & 3.0 \\
\hline $400-410$ & 14.6 & 6.95 & 42 & 25 & 197 & 21 & 3.6 & 0.7 & .09 & .02 & 51 & 22 & 7.2 & 3.7 & 7.4 & 3.2 \\
\hline
\end{tabular}

* $\mathrm{V}=$ urine flow; $\mathrm{U}_{\mathrm{Na}} \mathrm{V}$ and $\mathrm{U}_{\mathrm{K}} \mathrm{V}=$ urinary sodium and potassium excretion; $\mathrm{U}_{\mathrm{Na}}$ and $\mathrm{U}_{\mathrm{osm}}=$ urinary sodium concentration and urinary osmolality; $C_{o s m}$ and $C_{\mathrm{H}_{2} \mathrm{O}}=$ solute and free water clearance. $\mathrm{L}$ and $\mathrm{R}$ refer to the left and right kidney. $\mathrm{PAH}=$ para-aminohippurate. 
TABLE II

Experiments performed under hydrated conditions in which renal arterial constriction did not produce distinct differences in GFR between the two kidneys*

\begin{tabular}{|c|c|c|c|c|c|c|c|c|c|c|c|c|c|c|c|c|}
\hline & \multicolumn{2}{|c|}{ v } & \multicolumn{2}{|c|}{$\begin{array}{l}\text { Inulin } \\
\text { clearance }\end{array}$} & \multicolumn{2}{|c|}{$\mathrm{U}_{\mathrm{NaV}}$} & \multicolumn{2}{|c|}{ 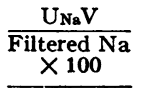 } & \multicolumn{2}{|c|}{$\frac{\mathrm{U}_{\mathrm{Na}}}{\mathrm{U}_{\mathrm{osm}}}$} & \multicolumn{2}{|c|}{$\mathrm{UKV}_{\mathrm{K}}$} & \multicolumn{2}{|c|}{$C_{\text {osm }}$} & \multicolumn{2}{|c|}{$\mathrm{C}_{2} \mathrm{O}$} \\
\hline & $\mathbf{R}$ & L & $\mathbf{R}$ & L & $\mathbf{R}$ & $\bar{L}$ & $\mathbf{R}$ & $\mathbf{L}$ & $\mathbf{R}$ & $\bar{L}$ & $\mathbf{R}$ & L & $\mathbf{R}$ & L & $\mathbf{R}$ & L \\
\hline & \multicolumn{2}{|c|}{$m l / m i n$} & \multicolumn{2}{|c|}{$m l / \min$} & \multicolumn{2}{|c|}{$\mu E q / \min$} & \multicolumn{2}{|c|}{$\%$} & & & \multicolumn{2}{|c|}{$\mu E q / \min$} & \multicolumn{2}{|c|}{$m l / \min$} & \multicolumn{2}{|c|}{$\operatorname{ml} / \min$} \\
\hline $\begin{array}{l}1 . \dagger \\
2 . \\
3 .\end{array}$ & $\begin{array}{l}3.5 \\
3.6 \\
5.9\end{array}$ & $\begin{array}{l}3.9 \\
1.7 \\
3.3\end{array}$ & $\begin{array}{l}27 \\
28 \\
29\end{array}$ & $\begin{array}{l}30 \\
29 \\
31\end{array}$ & $\begin{array}{l}118 \\
140 \\
194\end{array}$ & $\begin{array}{r}130 \\
40 \\
38\end{array}$ & $\begin{array}{l}3.3 \\
4.0 \\
5.3\end{array}$ & $\begin{array}{l}3.3 \\
1.1 \\
1.0\end{array}$ & $\begin{array}{l}.28 \\
.29 \\
.21\end{array}$ & $\begin{array}{l}.28 \\
.19 \\
.06\end{array}$ & $\begin{array}{l}15 \\
17 \\
26\end{array}$ & $\begin{array}{l}16 \\
12 \\
18\end{array}$ & $\begin{array}{l}1.4 \\
1.7 \\
3.4\end{array}$ & $\begin{array}{l}1.6 \\
0.7 \\
2.2\end{array}$ & $\begin{array}{l}2.1 \\
1.9 \\
2.5\end{array}$ & $\begin{array}{l}2.3 \\
1.0 \\
1.1\end{array}$ \\
\hline $\begin{array}{l}1 . \dagger \\
2 . \\
3 .\end{array}$ & $\begin{array}{l}2.9 \\
5.0 \\
8.1\end{array}$ & $\begin{array}{l}3.3 \\
3.3 \\
5.2\end{array}$ & $\begin{array}{l}54 \\
55 \\
56\end{array}$ & $\begin{array}{l}57 \\
57 \\
55\end{array}$ & $\begin{array}{l}32 \\
29 \\
63\end{array}$ & $\begin{array}{l}39 \\
12 \\
17\end{array}$ & $\begin{array}{l}0.4 \\
0.4 \\
0.9\end{array}$ & $\begin{array}{l}0.5 \\
0.2 \\
0.2\end{array}$ & $\begin{array}{l}.07 \\
.04 \\
.06\end{array}$ & $\begin{array}{l}.08 \\
.02 \\
.02\end{array}$ & $\begin{array}{l}34 \\
28 \\
28\end{array}$ & $\begin{array}{l}37 \\
22 \\
22\end{array}$ & $\begin{array}{l}1.5 \\
2.4 \\
3.9\end{array}$ & $\begin{array}{l}1.7 \\
2.2 \\
3.1\end{array}$ & $\begin{array}{l}1.4 \\
2.6 \\
4.2\end{array}$ & $\begin{array}{l}1.6 \\
1.1 \\
2.1\end{array}$ \\
\hline $\begin{array}{l}1 . \dagger \\
2 . \\
3 .\end{array}$ & $\begin{array}{l}3.3 \\
3.2 \\
7.2\end{array}$ & $\begin{array}{l}3.7 \\
1.8 \\
5.3\end{array}$ & $\begin{array}{l}21 \\
21 \\
19\end{array}$ & $\begin{array}{l}23 \\
21 \\
20\end{array}$ & $\begin{array}{l}21 \\
16 \\
51\end{array}$ & $\begin{array}{r}26 \\
3 \\
11\end{array}$ & $\begin{array}{l}0.8 \\
0.7 \\
2.6\end{array}$ & $\begin{array}{l}0.9 \\
0.1 \\
0.5\end{array}$ & $\begin{array}{l}.05 \\
.04 \\
.05\end{array}$ & $\begin{array}{l}.06 \\
.01 \\
.01\end{array}$ & $\begin{array}{l}21 \\
19 \\
31\end{array}$ & $\begin{array}{l}20 \\
10 \\
22\end{array}$ & $\begin{array}{l}1.4 \\
1.3 \\
3.8\end{array}$ & $\begin{array}{l}1.6 \\
1.0 \\
3.0\end{array}$ & $\begin{array}{l}1.9 \\
1.9 \\
3.4\end{array}$ & $\begin{array}{l}2.1 \\
0.8 \\
2.2\end{array}$ \\
\hline
\end{tabular}

* See Table I for abbreviations.

$\dagger 1$, collection periods obtained before left renal arterial constriction; 2 , collection periods obtained after renal arterial constriction; 3 , collection periods obtained subsequently during the course of the mannitol diuresis.

mained lower in the constricted kidney throughout the osmotic diuresis (Tables I to III, Figure 1).

After constriction potassium excretion decreased in the experimental kidney (Tables I to III).

In the present studies the plasma sodium concentration in each collection period was identical for both kidneys. Therefore, the urinary sodium concentration obtained simultaneously from both kidneys may be utilized to compare the transtubular sodium concentration gradient established by each kidney. Variations in sodium concentration resulting solely from differences in water reabsorption in the two kidneys may be eliminated by factoring urinary sodium concentration by total urinary osmolality.
In every experiment this reduction in potassium excretion was proportionately greater than the fall in filtered sodium (Figure 2).

After water hydration renal arterial constriction resulted in a prompt fall in $\mathrm{C}_{\mathrm{H}_{2} \mathrm{O}}$ in the experimental kidney (Tables I and II, Figure 3). In several studies this decrease in $\mathrm{C}_{\mathrm{H}_{2} \mathrm{O}}$ was not associated with distinct differences in GFR between the two kidneys (Table II). During the course of the subsequent osmotic diuresis $\mathrm{C}_{\mathrm{H}_{2} \mathrm{O}}$ rose in both kidneys, but in each collection period remained lower on the constricted side (Tables I

TABLE III

Typical experiment performed under hydropenic conditions*

\begin{tabular}{|c|c|c|c|c|c|c|c|c|c|c|c|c|c|c|c|c|}
\hline \multirow[b]{2}{*}{ Time } & \multicolumn{2}{|c|}{ V } & \multicolumn{2}{|c|}{$\begin{array}{l}\text { Inulin } \\
\text { clearance }\end{array}$} & \multicolumn{2}{|c|}{$\mathrm{UNa}_{\mathrm{Na}} \mathrm{V}$} & \multicolumn{2}{|c|}{$\frac{\mathrm{U}_{\mathrm{NaV}}}{\underset{\text { Filtered Na }}{\times 100}}$} & \multicolumn{2}{|c|}{$\frac{\mathrm{U}_{\mathrm{Na}}}{\mathrm{U}_{\mathrm{OBm}}}$} & \multicolumn{2}{|c|}{$\mathrm{U}_{\mathbf{K}} \mathrm{V}$} & \multicolumn{2}{|c|}{ Cosm } & \multicolumn{2}{|c|}{$\mathrm{T}^{\mathrm{C}} \mathrm{H}_{2} \mathrm{O}$} \\
\hline & $\overline{\mathbf{R}}$ & L & $\mathbf{R}$ & L & $\mathbf{R}$ & L & $\mathbf{R}$ & L & $\mathbf{R}$ & L & $\mathbf{R}$ & $\bar{L}$ & $\mathbf{R}$ & L & $\bar{R}$ & $\mathbf{L}$ \\
\hline $\min$ & \multicolumn{2}{|c|}{$m l / m i n$} & \multicolumn{2}{|c|}{$m l / m i n$} & \multicolumn{2}{|c|}{$\mu E q / \min$} & \multicolumn{2}{|c|}{$\%$} & & & \multicolumn{2}{|c|}{$\mu E q / \min$} & \multicolumn{2}{|c|}{$m l / \min$} & \multicolumn{2}{|c|}{$m l / m i n$} \\
\hline 0 & \multirow{2}{*}{\multicolumn{16}{|c|}{$\begin{array}{l}\text { Primes administered. Constant infusion started: inulin } 25 \mathrm{mg} \text { per minute, PAH } 4 \mathrm{mg} \text { per minute, vasopressin } 50 \mathrm{mU} \text { per } \mathrm{kg} \text { per } \\
\text { hour in } 0.9 \% \mathrm{NaCl} \text { at } 0.5 \mathrm{ml} \text { per minute. } 10 \% \text { mannitol in } 0.3 \% \mathrm{NaCl} \text { administered intravenously at } 4 \mathrm{ml} \text { per minute. } \\
\text { Surgery completed. }\end{array}$}} \\
\hline 60 & & & & & & & & & & & & & & & & \\
\hline $95-105$ & 1.98 & 1.98 & 40 & 44 & 172 & 216 & 2.9 & 3.3 & .12 & .16 & 40 & 48 & 4.4 & 4.4 & 2.5 & 2.4 \\
\hline $105-115$ & 1.96 & 1.97 & 38 & 43 & 163 & 207 & 2.9 & 3.2 & .12 & .15 & 39 & 47 & 4.4 & 4.4 & 2.5 & 2.5 \\
\hline $115-170$ & \multicolumn{16}{|c|}{ Constriction of left renal artery. } \\
\hline $170-180$ & 2.54 & 1.29 & 39 & 35 & 249 & 27 & 4.3 & 0.5 & .15 & .03 & 51 & 24 & 5.2 & 2.9 & 2.7 & 1.6 \\
\hline 180 & \multicolumn{16}{|c|}{$10 \%$ mannitol in $0.3 \% \mathrm{NaCl}$ administered at increasing rates throughout the remainder of the study. } \\
\hline $200-210$ & 3.73 & 1.82 & 40 & 32 & 343 & 71 & 5.7 & 1.5 & .16 & .06 & 75 & 27 & 6.7 & 3.7 & 3.0 & 1.9 \\
\hline $210-220$ & 3.95 & 2.07 & 40 & 37 & 356 & 52 & 6.0 & 1.0 & .16 & .04 & 75 & 23 & 6.9 & 4.1 & 3.0 & 2.1 \\
\hline $220-230$ & 5.33 & 2.15 & 41 & 30 & 474 & 65 & 8.0 & 1.5 & .17 & .05 & 96 & 24 & 8.5 & 4.0 & 3.1 & 1.9 \\
\hline $230-240$ & 6.55 & 2.49 & 41 & 31 & 642 & 27 & 10.7 & 0.6 & .21 & .02 & 92 & 17 & 9.7 & 4.5 & 3.1 & 2.0 \\
\hline $240-250$ & 7.30 & 3.30 & 41 & 35 & 591 & 83 & 9.9 & 1.7 & .18 & .04 & 95 & 26 & 10.4 & 5.7 & 3.1 & 2.4 \\
\hline $250-260$ & 8.45 & 3.80 & 42 & 33 & 676 & 106 & 11.2 & 2.2 & .18 & .05 & 110 & 27 & 11.6 & 6.3 & 3.2 & 2.5 \\
\hline
\end{tabular}

* See Table I for abbreviations. Also, $\mathrm{T}^{\circ} \mathrm{HzO}=$ free water reabsorption. 


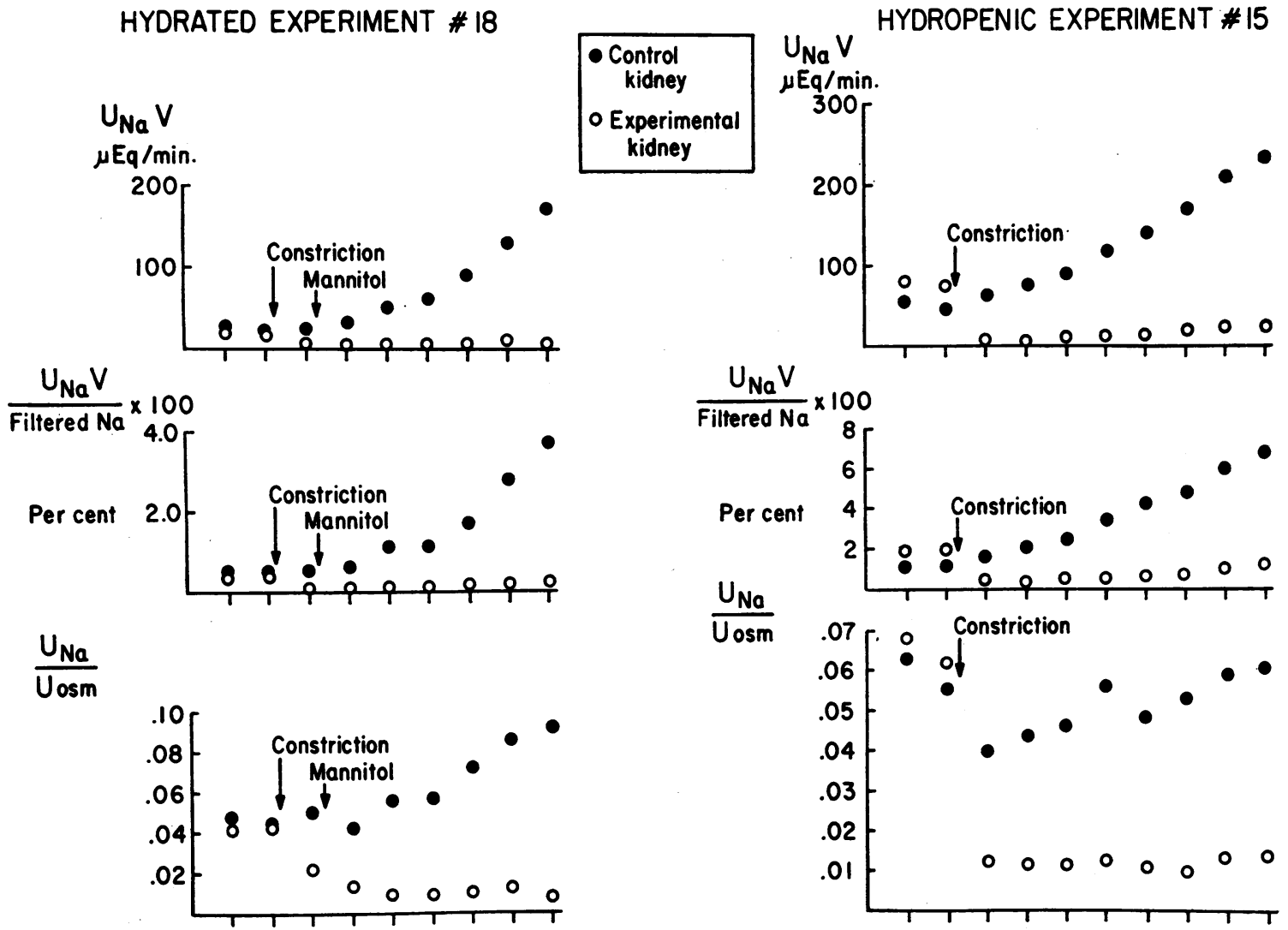

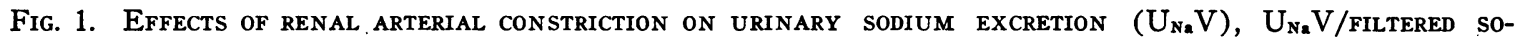
DIUM, AND URINARY SODIUM CONCENTRATION/URINARY OSMOLALITY ( $U_{N_{a} /} / U_{o s m}$ ) DURING THE COURSE OF TYPICAL EXPERIMENTS PERFORMED UNDER HYDRATED AND HYDROPENIC CONDITIONS. The vertical bars on the abscissa represent suCcessive collection periods in each study.

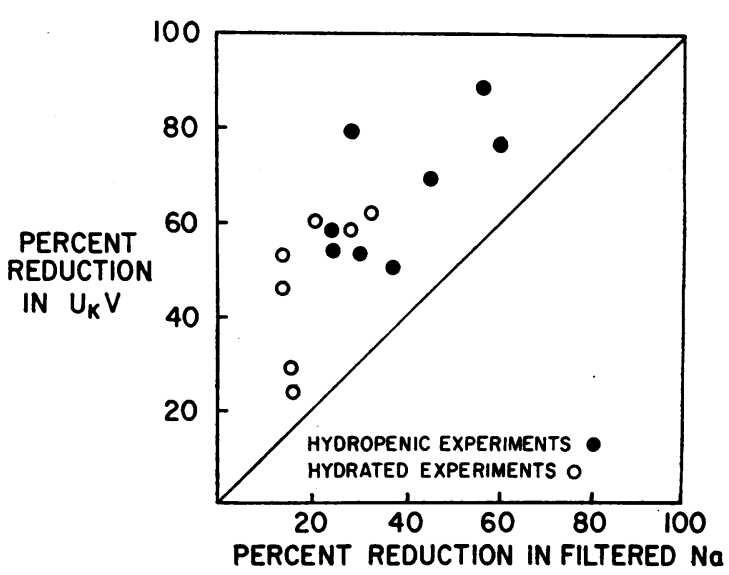

Fig. 2. PER CENT Reduction IN POTASSIUM EXCRETION ( $U_{\mathrm{K}} \mathrm{V}$ ) COMPARED TO THE PER CENT REDUCTION IN FILTERED SODIUM IMMEDIATELY AFTER RENAL ARTERIAL CONSTRICTION IN ALL EXPERIMENTS. and II, Figure 3). In all studies $\mathrm{C}_{\mathrm{H}_{2} \mathrm{O}} / \mathrm{GFR}$ plus $\mathrm{C}_{\mathrm{Na}} / \mathrm{GFR}$ fell immediately after renal arterial constriction and, during the course of the osmotic diuresis, rose more slowly on the constricted side (Figure 3). Although $\mathrm{C}_{\mathrm{H}_{2} \mathrm{O}}$ rose linearly as $\mathrm{C}_{\mathrm{osm}}$ increased in both kidneys, $\mathrm{C}_{\mathrm{H}_{2} \mathrm{O}}$ per $\mathrm{C}_{\text {osm }}$ remained consistently lower in the constricted kidney (Figure 4). Similar findings were obtained when $\mathrm{C}_{\mathrm{H}_{2} \mathrm{O}} / \mathrm{GFR}$ was plotted against $\mathrm{C}_{\mathrm{osm}} / \mathrm{GFR}^{2}$ (Figure 4).

${ }^{2}$ Since GFR was generally lower on the constricted side, it is apparent that at every level of $\mathrm{C}_{\text {osm }}$ the fraction of the filtered solute load appearing in the urine was appreciably greater on the constricted side. Factoring $\mathrm{C}_{\text {osm }}$ by GFR permits a comparison of the two kidneys at equivalent levels of fractional solute excretion. However, in the presence of a reduction in GFR, it may also be inappropriate to compare absolute levels of $\mathrm{C}_{\mathrm{H}_{2} \mathrm{O}}$ per level of $\mathrm{C}_{\text {osm }} / \mathrm{GFR}$. Therefore, $\mathrm{C}_{\mathrm{H}_{20} \mathrm{O}}$ has also been factored by GFR. 
EXP. \# 8

EXP $\# 9$
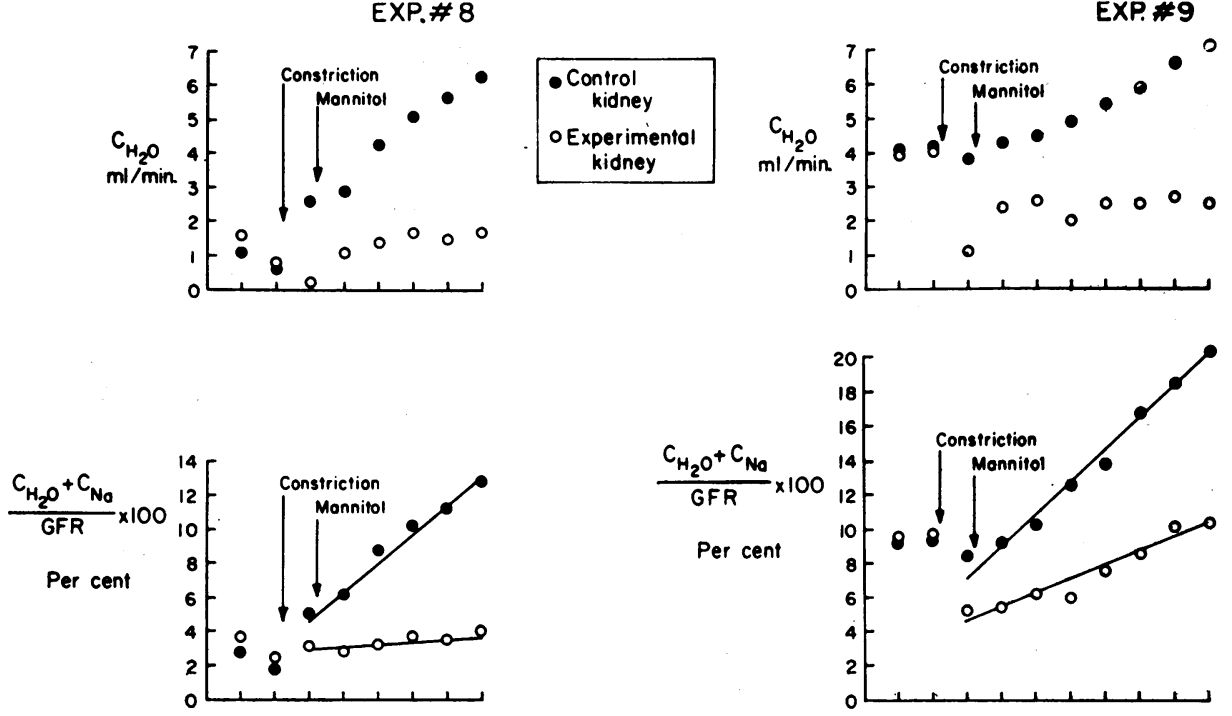

$E X P, \# 13$
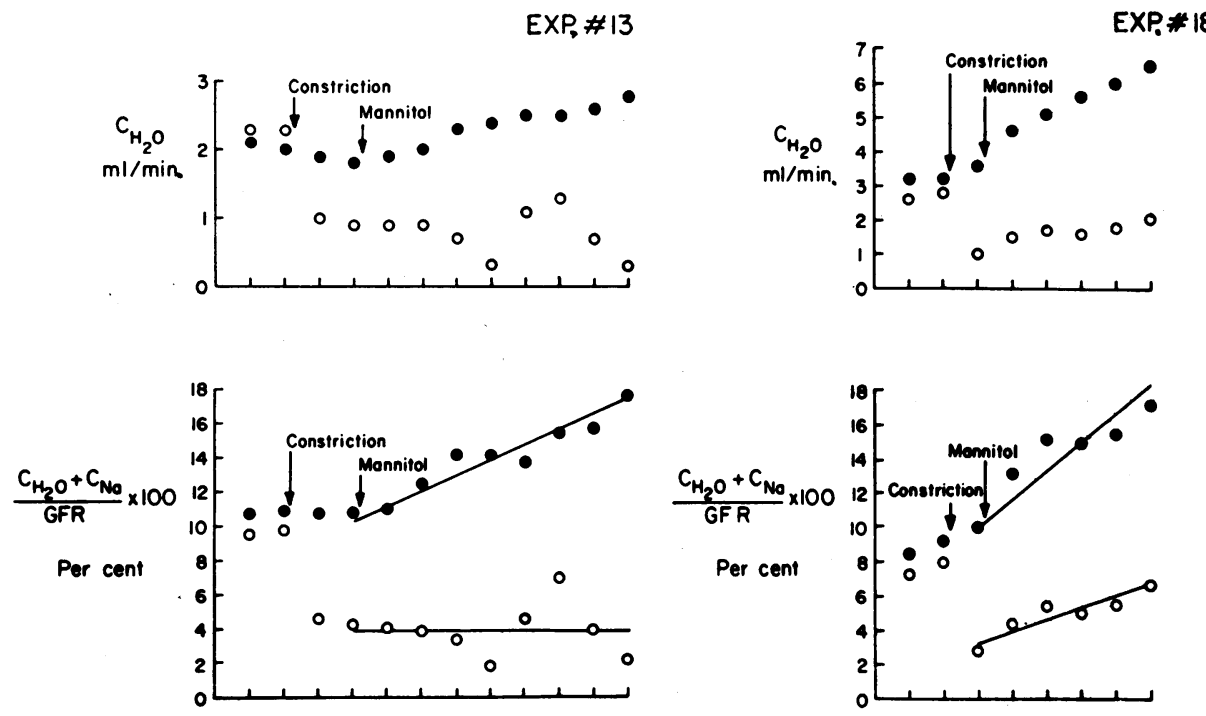

Fig. 3. Effects of Renal arterial constriction on $\mathrm{C}_{\mathrm{H}_{2} \mathrm{O}}$ and $\mathrm{C}_{\mathrm{H}_{2} \mathrm{O}} / \mathrm{GFR}$ plus $\mathrm{C}_{\mathrm{Na}} / \mathrm{GFR}$ DURING THE COURSE OF FOUR EXPERIMENTS PERFORMED UNDER HYDRATED CONDITIONS. $\mathrm{C}_{\mathrm{H}_{2} \mathrm{O}}$ and $\mathrm{C}_{\mathrm{Na}}=$ free water and sodium clearance; $\mathrm{GFR}=$ glomerular filtration rate. The vertical bars on the abscissa represent successive collection periods in each study. $\mathrm{C}_{\mathrm{H}_{2} \mathrm{O}} / \mathrm{GFR}$ plus $\mathrm{C}_{\mathrm{Na}} / \mathrm{GFR}$ has been utilized as an indirect index of the fraction of the filtered sodium load reaching the ascending limb.

In the studies performed under hydropenic conditions, $\mathrm{T}_{\mathrm{H}_{2} \mathrm{O}}^{\mathrm{O}}$ in the control kidney rose to maximal levels, plateaued, and often fell toward $\mathrm{C}_{\mathrm{H}_{2} \mathrm{O}}$ as the osmotic diuresis increased (Table III, Figure 5). After constriction of the renal artery, $\mathrm{T}^{\mathrm{c}} \mathrm{H}_{2} \mathrm{O}$ fell in the constricted kidney and in each collection period during the osmotic diuresis remained lower on the constricted side (Table III,
Figure 5). Furthermore, immediately after constriction $\mathrm{T}^{\mathrm{c}}{ }_{\mathrm{H}_{2} \mathrm{O}} / \mathrm{GFR}$ fell in the experimental kidney (Figure 5). During the subsequent diuresis, $\mathrm{T}^{\mathrm{c}} \mathrm{H}_{2} \mathrm{O} / \mathrm{GFR}$ increased in both kidneys; however, this parameter continued to rise in the constricted kidney after maximal levels had been obtained in the control kidney (Figure 5).

Small quantities of saline were administered 
with mannitol in several studies in order to prevent a profound fall in plasma sodium concentration (6). The addition of saline did not qualitatively alter the results.

\section{Discussion}

After unilateral renal arterial constriction, $\mathrm{U}_{\mathrm{Na}} \mathrm{V}$, $\mathrm{U}_{\mathrm{Na}} \mathrm{V} /$ filtered sodium, and $\mathrm{U}_{\mathrm{Na}} / \mathrm{U}_{\mathrm{osm}}$ decreased sharply in the experimental kidney (Tables I to III, Figure 1). Thereafter, during mannitol loading, these parameters could be increased only slightly in the constricted kidney (Tables I to III, Figure 1). Since $U_{\mathrm{Na}} / \mathrm{U}_{\text {osm }}$ is an index of the sodium reabsorptive gradient, it appears that the transtubular sodium concentration gradient established by the renal tubule was increased on the
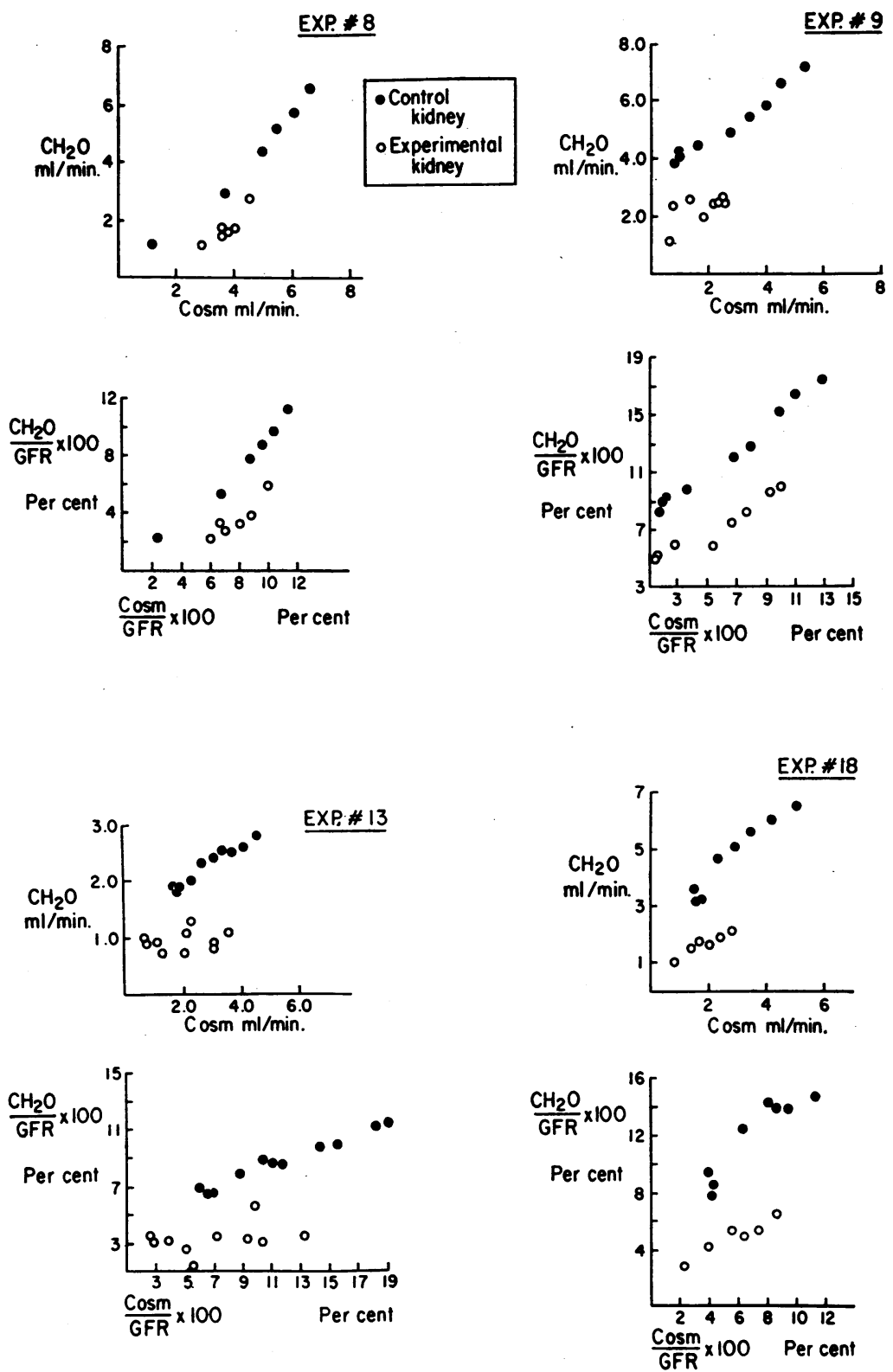

Fig. 4. C $\mathrm{H}_{2} \mathrm{O}$ plotted against solute clearance ( $\mathrm{C}_{\text {osm }}$ ) and $\mathrm{C}_{\mathrm{H}_{2} \mathrm{O}} / \mathrm{GFR}$ PLOTTED AGAINST Cosm/GFR IN FOUR EXPERIMENTS PERFORMEd UNDER HYDRATED CONDITIONS. 
constricted side. Furthermore, despite a progressive rise (increments several times the original) in the concentration of mannitol in the glomerular filtrate the enhanced capacity for sodium reabsorption could not be overcome on the constricted side (Figure 1).

Numerous studies have suggested that $\mathrm{C}_{\mathrm{H}_{2} \mathrm{O}}$ depends on the rate of transport of absorbable solute (sodium) without water at the ascending limb of the loop of Henle and distal tubule. In this context, the rise in $\mathrm{C}_{\mathrm{H}_{2} \mathrm{O}}$ associated with an increasing solute diuresis has been attributed to increasing rates of distal sodium supply and transport (7). Alternatively, it has also been proposed that the rise in $\mathrm{C}_{\mathrm{H}_{2} \mathrm{O}}$ during mannitol loading may be related, in part, to a progressive decrease in the back diffusion of water at distal sites as the rate of excretion of nonreabsorbable solute increases (8). In this view, the reduction in $\mathrm{C}_{\mathrm{H}_{2} \mathrm{O}}$ in the present studies may have resulted solely from increased back diffusion of water as a consequence of the reduced rate of solute excretion on the constricted side. At every level of $\mathrm{C}_{\mathrm{osm}}$, however, $\mathrm{C}_{\mathrm{H}_{2} \mathrm{O}}$ was consistently lower in the constricted kidney (Figure 4). Moreover, at every level of fractional solute excretion, the fraction of the filtered water load "freed" was also lower on the constricted side (Figure 4). These findings suggest that the reduction in $\mathrm{C}_{\mathrm{H}_{2} \mathrm{O}}$ after renal arterial constriction could not be explained entirely by enhanced back diffusion of water in the experimental kidney. We propose, therefore, that the reduced $\mathrm{C}_{\mathrm{H}_{2} \mathrm{O}}$ in the constricted kidney was consequent to a decreased supply and transport of sodium at distal water clearing sites.

Since $\mathrm{C}_{\mathrm{H}_{2} \mathrm{O}}$ is a reflection of distal sodium transport, $\mathrm{C}_{\mathrm{H}_{2} \mathrm{O}} / \mathrm{GFR}$ may be utilized as an index of the fraction of the filtered sodium load reabsorbed in the distal tubule. The sum of $\mathrm{C}_{\mathrm{H}_{2} \mathrm{O}} / \mathrm{GFR}$ and $\mathrm{C}_{\mathrm{Na}} / \mathrm{GFR}$ may provide an indirect index of the fraction of the filtered sodium load reaching the ascending limb. Insofar as these assumptions are correct, the finding that $\mathrm{C}_{\mathrm{H}_{2} \mathrm{O}}$ /GFR plus $\mathrm{C}_{\mathrm{Na}} / \mathrm{GFR}$ fell after renal arterial constriction (Figure 3 ) implies that the fraction of the filtered sodium load reaching distal sites was reduced in the constricted kidney. The lower $\mathrm{C}_{\mathrm{H}_{2} \mathrm{O}}$ noted on the experimental side in several studies in which there were no distinct differences in GFR between the two kidneys (Table II) further suggests that constriction of

\section{EXPERIMENT \# I}

\section{EXPERIMENT \# 2}

EXPERIMENT \# 15

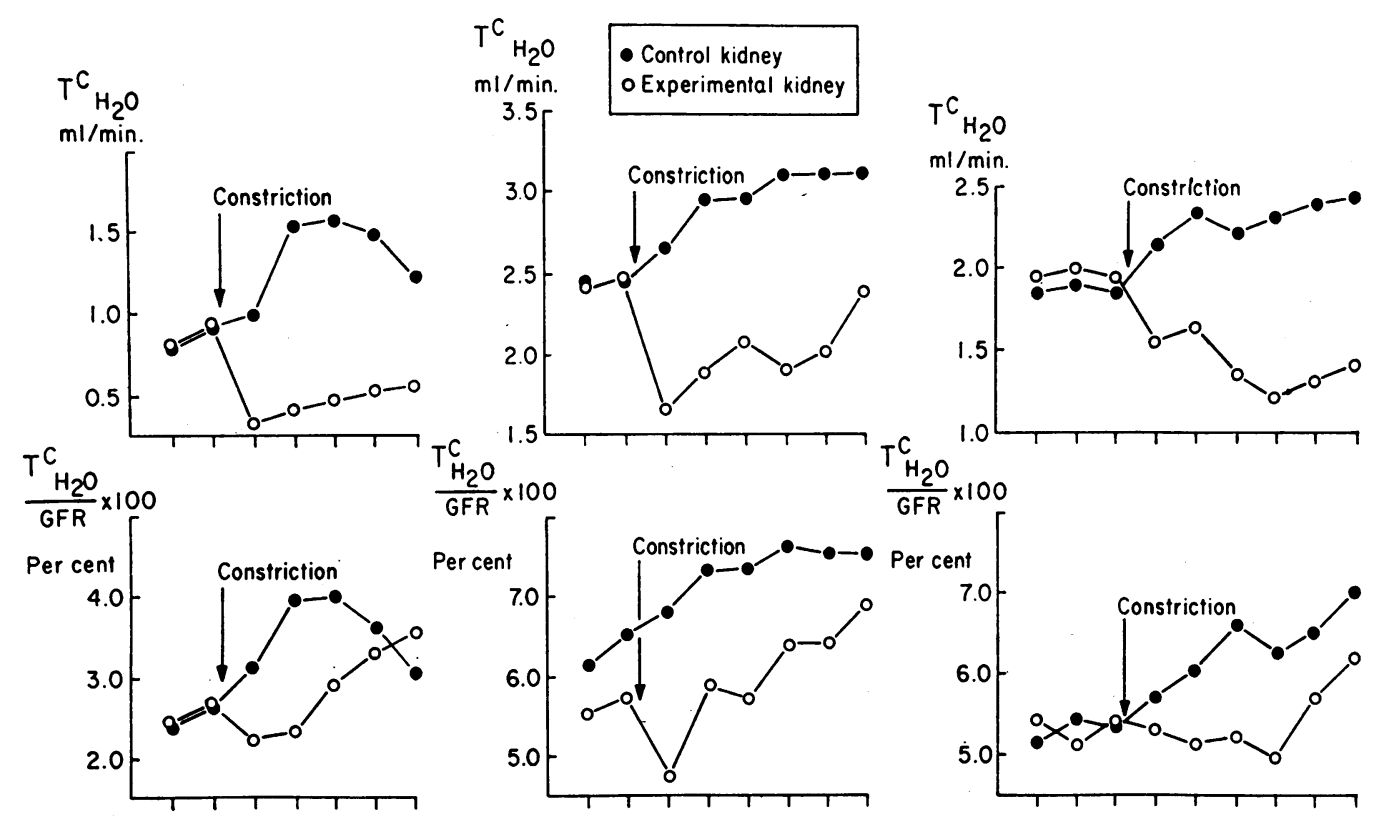

Fig. 5. EFFECTS OF RENAL ARTERIAL CONSTRICTION ON FREE WATER REABSORPTION ( $\mathrm{T}^{\mathrm{c}} \mathrm{H}_{2} \mathrm{O}$ ) AND $\mathrm{T}^{\mathrm{c}} \mathrm{H}_{2} \mathrm{O} /$ GFR DURING THE COURSE OF THREE EXPERIMENTS PERFORMED UNDER HYDROPENIC CONDITIONS. The vertical bars on the abscissa represent successive collection periods in each study. 
the renal artery reduced fractional distal sodium supply. It may be concluded, therefore, that the fraction of the filtered sodium load reabsorbed in the proximal tubule was increased after renal arterial constriction. Furthermore, despite identical concentrations of mannitol (or sodium) in the filtrate of both kidneys at any point in time, fractional distal sodium supply rose more slowly on the constricted side as the mannitol load was increased (Figure 3). For example, in experiment 13 (Figure 3 ), the index of fractional distal sodium supply increased from $10 \%$ to $18 \%$ on the control side while this index remained at approximately $4 \%$ on the constricted side. Thus, the enhanced fractional proximal sodium reabsorption appears to have blunted the capacity for mannitol to increase distal sodium supply in the constricted kidney.

During loading with nonreabsorbable solute, proximal fractional sodium reabsorption decreases as a result of a limiting sodium concentration gradient between proximal tubular fluid and plasma $(9,10)$. Under these conditions, enhanced fractional sodium reabsorption in the proximal tubule implies an increase in the transtubular sodium concentration gradient established at this site. Thus, during mannitol loading, constriction of the renal artery would lower the concentration of sodium reaching the ascending limb. The lower $\mathrm{U}_{\mathrm{Na}} / \mathrm{U}_{\text {osm }}$ found on the constricted side (Tables I to III, Figure 1) may, therefore, reflect a process that develops, in part, within the proximal tubule.

Data from studies performed under hydropenic conditions were analyzed in a similar manner and found to be entirely consistent with the conclusions derived from the hydrated studies. After renal arterial constriction, $\mathrm{T}^{\mathbf{c}}{ }_{\mathrm{H}_{2} \mathrm{O}}$ fell and in each collection period thereafter remained lower on the constricted side (Table III, Figure 5). Insofar as $\mathrm{T}^{\mathrm{c}} \mathrm{H}_{2} \mathrm{O}$ represents an indirect index of ascending limb sodium supply and transport $(4,11,12)$, these data suggest that constriction of the renal artery decreased sodium supply and transport at this site. Since $\mathrm{T}^{\mathrm{c}} \mathrm{H}_{2} \mathrm{O} / \mathrm{GFR}$ also fell after renal arterial constriction (Figure 5), it would appear that the fraction of the filtered sodium load reaching the ascending limb and transported at this site was reduced on the experimental side. Thus, studies performed in the hydropenic state also suggest that constriction of the renal artery during mannitol loading increases the fraction of the filtered load reabsorbed in the proximal tubule.

Recent studies have implied that the plateau and subsequent fall in $\mathrm{T}^{\mathrm{c}}{ }_{\mathrm{H}_{2} \mathrm{O}}$, occurring at high levels of $\mathrm{C}_{\mathrm{osm}}$, may represent a failure of distal tubular fluid to reattain isotonicity $(13,14)$. This failure to reattain isotonicity may depend in part on the rate of sodium transport at the ascending limb and the resulting quantity of hypotonic fluid formed at this site. In this context, ascending limb sodium transport would be greater during the plateau (or subsequent fall) in $\mathrm{T}_{\mathrm{H}_{2} \mathrm{O}}$ than during the initial rise in $\mathrm{T}_{\mathrm{H}_{2} \mathrm{O}}$. Therefore, the finding that $\mathrm{T}^{\mathrm{c}}{ }_{\mathrm{H}_{2} \mathrm{O}}$ and $\mathrm{T}^{\mathrm{c}} \mathrm{H}_{2} \mathrm{O} / \mathrm{GFR}$ continued to rise on the constricted side, after a plateau had been obtained on the control side (Figure 5), also implies that ascending limb sodium supply and transport increased more slowly in the constricted kidney. Thus, the data obtained in studies performed in the hydropenic state appear to be consistent with the proposal that constriction of the renal artery, during loading with nonreabsorbable solute, increases the gradient against which sodium can be reabsorbed in the proximal tubule.

Available evidence suggests that potassium excretion depends in large part on the rate at which sodium is presented to the $\mathrm{Na}: \mathrm{K}$ exchange site in the late distal tubule and collecting duct $(15,16)$. The finding that $U_{K} V$ fell proportionately more than the filtered load of sodium (Figure 2) is, therefore, also consistent with enhanced sodium reabsorption at a locus proximal to the $\mathrm{Na}: \mathrm{K}$ exchange site.

In our studies we have asumed that $\mathrm{C}_{\mathrm{H}_{2} \mathrm{O}}, \mathrm{C}_{\mathrm{H}_{2} \mathrm{O}}$ plus $\mathrm{C}_{\mathrm{Na}}$, and $\mathrm{T}^{\mathrm{c}} \mathrm{H}_{2} \mathrm{O}$ represent indexes of ascending limb sodium supply and transport. Insofar as these assumptions are valid, it would appear that constriction of the renal artery during mannitol loading enhances the sodium reabsorptive gradient, to a considerable extent, within the proximal tubule. However, the present data do not exclude the possibility that the gradient for sodium reabsorption was also enhanced at distal tubular sites.

Since the effects of renal arterial constriction were noted only in the experimental kidney, it would appear that the changes in tubular function could not be ascribed to the effects of a circulating hormone. It seems, therefore, that the enhanced sodium reabsorption was consequent to an alteration in renal hemodynamics provoked by constric- 
tion of the renal artery. Although GFR was generally reduced after constriction (Tables $I$ and III), enhanced reabsorption was also noted when there was no measurable reduction in GFR on the constricted side (Table II). Thus, some other hemodynamic factor or factors may also be responsible for the alteration in tubular function. Renal arterial constriction may have altered the relative distribution of blood flow between cortical and juxtamedullary glomeruli. However, the effects of such a redistribution of intrarenal blood flow on sodium transport could not be evaluated in the present studies.

On the basis of clearance and micropuncture studies it has been suggested that constriction of the renal artery with consequent reductions in GFR does not affect fractional sodium reabsorption in the proximal tubule $(5,17,18)$. These conclusions were based on experiments performed in the hydropenic state during modest saline diureses in dogs $(5,17)$ and in nondiuretic rats (18). In contrast, the present studies suggest that renal arterial constriction, during loading with nonreabsorbable solute or after water hydration, enhances fractional sodium reabsorption within the proximal tubule. It may be possible to reconcile these apparently discrepant conclusions by analyzing the characteristics of proximal tubular sodium reabsorption before renal arterial constriction under each experimental condition. During control (nondiuretic) conditions $(9,10,19)$ and saline diureses $(9,19)$, proximal reabsorption is not limited by a measurable sodium concentration gradient between proximal tubular fluid and plasma. However, during loading with nonreabsorbable solute, proximal reabsorption is diminished as a consequence of a limiting transtubular sodium concentration gradient established by the proximal tubule $(9,10)$. In addition, recent micropuncture studies in dog have suggested that the state of hydration, in the absence of mannitol, may also decrease fractional sodium reabsorption in the proximal tubule (20). It may be conjectured, therefore, that constriction of the renal artery may enhance proximal fractional sodium reabsorption when proximal reabsorption is first diminished by a limiting gradient, as develops during mannitol loading, or by some unknown mechanism, as in the state of hydration.

\section{Summary}

One renal artery was constricted in dogs during a water diuresis (hydrated studies) and during a modest mannitol diuresis (hydropenic studies). Thereafter, an increasing mannitol diuresis was induced in both groups of studies. Associated with the constriction, fractional sodium excretion and urinary sodium concentration decreased appreciably in the experimental kidney. It was concluded that constriction of the renal artery increased the gradient against which sodium could be reabsorbed in the experimental kidney. Moreover, despite progressive increments in the mannitol load, it was not possible to overcome this enhanced capacity for sodium reabsorption. These changes in tubular function could not be ascribed solely to the effects of a circulating hormone, but appeared to be related specifically to the alteration in renal hemodynamics.

In the experiments performed in the hydrated state, free water clearance was utilized as an index of the rate of distal sodium transport, and free water clearance/glomerular filtration rate $\left(\mathrm{C}_{\mathrm{H}_{2} \mathrm{O}}\right.$ / GFR) plus $\mathrm{C}_{\mathrm{Na}} / \mathrm{GFR}$ served as an index of the fraction of the filtered sodium load reaching the ascending limb. After renal arterial constriction $\mathrm{C}_{\mathrm{H}_{2} \mathrm{O}}$ and $\mathrm{C}_{\mathrm{H}_{2} \mathrm{O}} / \mathrm{GFR}$ plus $\mathrm{C}_{\mathrm{Na}} / \mathrm{GFR}$ decreased sharply and, as the mannitol load was increased, rose more slowly on the constricted side. Furthermore, free water clearance/solute clearance was consistently lower in the constricted kidney. We propose that after water hydration and during an osmotic diuresis renal arterial constriction enhances the capacity for sodium reabsorption, in part within the proximal tubule. Data on free water reabsorption obtained in the studies performed in the hydropenic state, as well as all potassium excretion data, were entirely consistent with this hypothesis.

\section{Acknowledgments}

The authors gratefully acknowledge the technical assistance of Edith Neubert, Sarah Chipoco, and Marie Auriana.

\section{References}

1. Selkurt, E. E., P. W. Hall, and M. P. Spencer. Influence of graded arterial pressure decrement on renal clearance of creatinine, $\mathrm{p}$-aminohippurate and sodium. Amer. J. Physiol. 1949, 159, 369. 
2. Thompson, D. D., and R. F. Pitts. Effects of alterations of renal arterial pressure on sodium and water excretion. Amer. J. Physiol. 1952, 168, 490.

3. Thompson, D. D., and M. J. Barrett. Urine flow and solute excretion during osmotic diuresis. Amer. J. Physiol. 1954, 176, 33.

4. Stein, R. M., B. H. Levitt, M. H. Goldstein, J. G. Porush, G. M. Eisner, and M. F. Levitt. The effects of salt restriction on the renal concentrating operations in normal, hydropenic man. J. clin. Invest. 1962, 41, 2101.

5. Stein, R. M., D. D. Bercovitch, and M. F. Levitt. Dual effects of saline loading on renal tubular sodium reabsorption in the dog. Amer. J. Physiol. 1964, 207, 826.

6. Giebisch, G., and R. Lozano. The effects of adrenal steroids and potassium depletion on the elaboration of an osmotically concentrated urine. J. clin. Invest. 1959, 38, 843.

7. Goldstein, M. H., M. F. Levitt, A. D. Hauser, and D. Polimeros. Effect of meralluride on solute and water excretion in hydrated man: comments on site of action. J. clin. Invest. 1961, 40, 731.

8. Orloff, J., H. N. Wagner, Jr., and D. G. Davidson. The effects of variations in solute excretion and vasopressin dosage on the excretion of water in the dog. J. clin. Invest. 1958, 37, 458.

9. Windhager, E. E., and G. Giebisch. Micropuncture study of renal tubular transfer of sodium chloride in the rat. Amer. J. Physiol. 1961, 200, 581.

10. Ullrich, K. J., B. Schmidt-Nielsen, R. O’Dell, G. Pehling, C. W. Gottschalk, W. E. Lassiter, and M. Mylle. Micropuncture study of composition of proximal and distal tubular fluid in rat kidney. Amer. J. Physiol. 1963, 204, 527.

11. Porush, J. G., M. H. Goldstein, G. M. Eisner, and M. F. Levitt. Effect of organomercurials on the renal concentrating operation in hydropenic man: comments on site of action. J. clin. Invest. 1961, 40, 1475.

12. Gottschalk, C. W., and M. Mylle. Micropuncture study of the mammalian urinary concentrating mechanism: evidence for the countercurrent hypothesis. Amer. J. Physiol. 1960, 196, 927.

13. Earley, L. E., M. Kahn, and J. Orloff. The effects of infusions of chlorothiazide on urinary dilution and concentration in the dog. J. clin. Invest. 1961, 40, 857.

14. Cohen, J. A., B. Goodman, S. L. Yunis, M. Kahn, and M. F. Levitt. Pyrogen-induced concentrating defect in the dog. Fed. Proc. 1963, 22, 278.

15. Davidson, D. G., N. G. Levinsky, and R. W. Berliner. Maintenance of potassium excretion despite reduction of glomerular filtration during sodium diuresis. J. clin. Invest. 1958, 37, 548.

16. Berliner, R. W. Renal mechanisms for potassium excretion. Harvey Lect. 1961, 55, 141.

17. Dirks, J. H., W. J. Cirksena, and R. W. Berliner. The effect of saline on sodium reabsorption by the proximal tubule of the dog. Fed. Proc. 1965, 24, 520.

18. Glabman, S., H. S. Aynedjian, and N. Bank. Micropuncture study of the effects of acute reductions in glomerular filtration rate on sodium and water reabsorption in the proximal tubules (abstract). J. clin. Invest. 1965, 44, 1050.

19. Giebisch, G., R. M. Klose, and E. E. Windhager. Micropuncture study of hypertonic sodium chloride loading in the rat. Amer. J. Physiol. 1964, 206, 687.

20. Clapp, J. R., J. F. Watson, and R. W. Berliner. Osmolality, bicarbonate concentration, and water reabsorption in proximal tubule of the dog nephron. Amer. J. Physiol. 1963, 205, 273. 